\title{
6. Das Problem der Raumzeit in der Quantengravitation
}

Gemeinsam mit dem Problem des fehlenden physikalisch motivierbaren, fundamentalen Prinzips und dem im vorausgehenden Kapitel erörterten Kontingenzproblem bildet das Problem der (Hintergrund-) Raumzeit das Dreigestirn der fundamentalen konzeptionellen Probleme des Stringansatzes, an dem nahezu alle Detailprobleme ankoppeln und von dem sie teilweise sogar ursächlich ihren Ausgang nehmen.

\subsection{Das Problem der Hintergrundraumzeit im Stringansatz}

Eine der besten Motivationen sowohl für eine konzeptionelle Vereinheitlichung wie für eine nomologische Vereinigung, und damit für eine Theorie der Quantengravitation in der ersten wie auch der zweiten Ausprägung, besteht in der Unverträglichkeit zwischen Allgemeiner Relativitätstheorie und den Quantenfeldtheorien bzw. der Quantenmechanik. ${ }^{327}$ Will man diese Unverträglichkeit im Rahmen einer Theorie der Quantengravitation durch eine (direkte oder auch indirekte) Quantisierung der Gravitation überwinden, wie es nicht zuletzt auch der Stringansatz versucht, so betrifft diese Quantisierung nicht zuletzt auch unmittelbar die Raumzeit. Denn eine Quantisierung der Gravitation entspricht, wenn die fundamentalen Einsichten der Allgemeinen Relativitätstheorie hinsichtlich des Verhältnisses von Gravitation und Raumzeit zutreffen, letztlich gerade einer Quantisierung der Raumzeit bzw. ihrer Metrik: also einer "Quantengeometrie".

"[...] general relativity is not just a theory of gravity - in an appropriate sense, it is also a theory of spacetime itself; and hence a theory of quantum gravity must have something to say about the quantum nature of space and time." (Butterfield / Isham (2001) 34) 
Trifft die Annahme zu, dass sich die grundlegenden Eigenschaften der Realität nur im Rahmen eines quantenphysikalischen Ansatzes erfassen lassen, so sind spätestens für den Bereich, für den die Gravitation etwa die gleiche Stärke wie die anderen Wechselwirkungen annimmt - die PlanckEbene -, metrische und vielleicht sogar topologische Fluktuationen und Unschärfen zu erwarten, die für die Beschreibung der Raumzeit und ihrer metrischen und topologischen Eigenschaften eine "Theorie der Quantengeometrie" erforderlich machen. Eine solche Theorie der Quantengravitation sollte in der Lage sein, die Eigenschaften und das Verhalten der Raumzeit auf dieser Ebene zu beschreiben. Das heisst aber letztlich, dass sie in der Lage sein sollte zu erklären, was Raum und Zeit überhaupt sind und wie sie sich etwa zur Materie verhalten. ${ }^{328}$

"The search for a quantum theory of gravity raises questions such as: What is space? What is time? What is the meaning of 'being somewhere'? What is the meaning of 'moving'? Is motion to be defined with respect to objects or with respect to space? Can we formulate physics without referring to time or to spacetime? And also: What is matter? What is causality? What is the role of the observer in physics? / Questions of this kind have played a central role in periods of major advances in physics. [...] Today, this manner of posing problems is often regarded as 'too philosophical' by many physicists. [...] To understand quantum spacetime, we have to return, once more, to those foundational issues. [...] The problem of quantum gravity will not be solved unless we reconsider these questions." (Rovelli (2004) 20)

Diese Fragen nach der Natur von Raum und Zeit und nach dem Verhältnis von Raum und Zeit zur Materie, deren anzustrebende Antworten zu den vorrangigen Desiderata einer zukünftigen Theorie der Quantengravitation gehören, erfahren jedoch im Stringansatz, der schliesslich nicht zuletzt eine nomologisch vereinheitlichte Beschreibung aller Wechselwirkungen ein-

\footnotetext{
328 Das spezifische Problem der Zeit in den Quantengravitationstheorien wird im folgenden nicht behandelt - im Gegensatz zum Problem der problematischen Raumzeitkonzeption des Stringansatzes bzw. im Gegensatz zum Problemfeld der Erfordernisse, die Quantengravitationstheorien hinsichtlich ihrer Raumzeitkonzeptionen mutmasslich erfüllen müssen, wenn unsere grundlegenden Einsichten über die Raumzeit, wie sie von der Allgemeinen Relativitätstheorie geliefert werden, zumindest grundsätzlich richtig sind. Zum spezifischen Problem der Zeit in der Quantengravitation bzw. im Stringansatz, siehe etwa Seiberg (2006), Abschnitt 6.
} 
schliesslich der Gravitation zu leisten beansprucht, keine Klärung. Der Stringansatz trägt (über die bisher empirisch völlig unbestätigte und immerhin problematische Festlegung der Dimensionalität hinaus) in seiner bisherigen Form nicht ernsthaft etwas zum Verständnis der Raumzeit und ihrer Dynamik bei.

Was aber noch viel gravierender ist: Es gelingt ihm nicht einmal ohne weiteres, Raum und Zeit im Hinblick auf den schon in der Allgemeinen Relativitätstheorie erreichten Standard angemessen zu behandeln. Dies stellt seinen Status als angemessenen Ansatz zur Überwindung der Unvereinbarkeiten zwischen Allgemeiner Relativitätstheorie und Quantenmechanik bzw. Quantenfeldtheorien nicht unwesentlich in Frage. Das entscheidende Problem in dieser Hinsicht lässt sich an der Verwendung einer statischen Hintergrundraumzeit im Stringansatz festmachen.

\section{Das Problem der Hintergrundraumzeit}

Von einer Theorie der Quantengravitation sollte man erwarten, dass sie, soweit sich keine ausreichend motivierten Gründe für eine gegenteilige Annahme vorbringen lassen, zumindest nicht hinter die fundamentaleren Einsichten ihrer Vorgängertheorien zurückfällt. Das Problem der Raumzeit im Stringansatz resultiert jedoch gerade daraus, dass dieser die grundsätzlichen Einsichten der Allgemeinen Relativitätstheorie hinsichtlich unserer Auffassung von Raum und Zeit grundlegend ignoriert und mit einer modelltheoretischen Grundlage arbeitet, die mit der von der Allgemeinen Relativitätstheorie einhergehenden Konzeption der Raumzeit vollständig unverträglich ist.

Eine der grundlegenden Einsichten aus der Allgemeinen Relativitätstheorie besteht darin, dass das Gravitationsfeld letztlich der Raumzeit bzw. ihrer Metrik entspricht.

"The gravitational field is not located in spacetime: it is with respect to it that things are localized." (Rovelli (1998) 19) 
Dies lässt sich in einer extremen Deutung vielleicht sogar so lesen, dass es in der Darstellung der Allgemeinen Relativitätstheorie eigentlich gar keine Gravitation mehr gibt, und dass das, was vormals als Gravitation bezeichnet wurde, eigentlich nur metrische Eigenschaften der Raumzeit sind.

"Einstein's major discovery is that spacetime and gravitational field are the same object. A common reading of this discovery is that there is no gravitational field: just a dynamical spacetime. In view of quantum theory, it is more illuminating and more useful to say that there is no spacetime, just the gravitational field." (Rovelli (2004) 266)

Wenn das Gravitationsfeld aber der Raumzeit bzw. ihren metrischen Eigenschaften entspricht, lässt es sich konsequenterweise nicht als Quantenphänomen beschreiben, welches wiederum auf einer vorgegebenen, schon mit einer Metrik ausgestatteten Raumzeit stattfindet. Eine Theorie der Quantengravitation müsste vielmehr das Zustandekommen der Gravitation, und damit konsequenterweise das Zustandekommen der metrischen Eigenschaften der Raumzeit, vielleicht sogar der Raumzeit selbst, beschreiben, ohne dass diese Raumzeit mit allen ihren Eigenschaften schon vorausgesetzt wird. Wenn Gravitation mit der Raumzeit bzw. ihren metrischen Eigenschaften gleichzusetzen ist, so kann man nicht die Gravitation wiederum als Quantenphänomen auf einer vorgegebenen Hintergrundmetrik beschreiben wollen. Für eine quantenmechanische Behandlung der Gravitation, also eine Theorie der Quantengravitation, die gleichzeitig eine Beschreibung der "Quantengeometrie" leisten sollte, lässt sich vielmehr die Notwendigkeit einer Beschreibung ohne vorgegebenen Hintergrundraum erwarten.

"[...] gravity is geometry whence, in a fundamental theory, there should be no background metric. In quantum gravity, geometry and matter should both be 'born quantum mechanically'." (Ashtekar (2005) 12)

Eine weitere Einsicht aus der Allgemeinen Relativitätstheorie - eng verbunden mit der soeben geschilderten - besteht darin, dass die Raumzeit selbst, infolge der Identität ihrer metrischen Eigenschaften mit dem Gravitationsfeld, dynamisch ist. Die Raumzeit und ihre metrischen Eigenschaften sind Teil der Dynamik und nicht etwa ihr Schauplatz. Auch dies spricht ganz entschieden für die Unangemessenheit eines fest vorgegebenen, stati- 
schen Hintergrundraumes für eine angemessene Theorie der Quantengravitation.

"But the world is not formed by a fixed background over which things happen. The background itself is dynamical. [...] The absence of a fixed background in nature (or active diffeomorphism invariance) is the key general lesson we have learned from gravitational theories." (Rovelli (1998) 5)

Ein deutliches Indiz für die Dynamizität der Raumzeit und für die Hintergrundunabhängigkeit des kosmischen Geschehens liefert nicht zuletzt die Diffeomorphismus-Invarianz ${ }^{329}$ der Allgemeinen Relativitätstheorie. Die Diffeomorphismus-Invarianz kommt vor allem im Einsteinschen LochArgument und seinen moderneren Varianten ${ }^{330}$ zum Ausdruck. Deutlich wird sie zudem in der von der Allgemeinen Relativitätstheorie vorhergesagten Zahl der Freiheitsgrade von Gravitationswellen und in den indirekten empirischen Belegen, die es für diese inzwischen immerhin gibt:

"The observations that show that gravitational radiation carries energy away from binary pulsars in two degrees of freedom of radiation, exactly as predicted by Einstein's theory, may be considered the experimental death blow to the absolute point of view. The fact that two, and not five, degrees of freedom are observed means that the gauge invariance of the laws of nature includes spacetime diffeomorphism invariance. This means that the metric is a completely dynamical entity, and no component of the metric is fixed and non-dynamical. / As argued by Einstein and many others since, the diffeomorphism invariance is tied directly to the background independence of the theory. This is shown by the hole argument [...]. / Thus, classical general relativity is background independent. The arena for its dynamics is no spacetime, instead the arena is the configuration space of all the degrees of freedom of the gravitational field, which is the metric modulo diffeomorphisms." (Smolin (2003) 12)

$329 \quad$ Ein Diffeomorphismus ist eine stetige, umkehrbare Abbildung einer Mannigfaltigkeit auf sich selbst oder eine andere Mannigfaltigkeit.

330 Siehe etwa Norton (1988), (2004), Earman / Norton (1987), Earman (1989), Butterfield (1989) sowie Rynasiewicz (1994). 
Infolge der Diffeomorphismus-Invarianz entspricht eine physikalische Raumzeit gemäss der Allgemeinen Relativitätstheorie nicht einer bestimmten Mannigfaltigkeit mit einer Metrik, sondern einer Äquivalenzklasse solcher Mannigfaltigkeiten unter der Transformationsgruppe des Diffeomorphismus. Die in einer solchen Äquivalenzklasse enthaltende Information lässt sich nicht mittels der Qualifizierung von Feldwerten an Raumzeitpunkten darstellen. Das bedeutet aber: Wenn die Darstellung der Allgemeinen Relativitätstheorie in dieser Hinsicht den Verhältnissen in der Natur gerecht wird, wofür ihre empirischen Bestätigungen sprechen, ist jede Theorie, die ihre entsprechenden Feldwerte oder dynamischen Grössen den Punkten einer vorgegebenen Hintergrundraumzeit zuordnet, für eine Beschreibung der tatsächlichen Verhältnisse letztlich unangemessen.

Dass sich gemäss der Allgemeinen Relativitätstheorie die in einer infolge der Diffeomorphismus-Invarianz zustandekommenden Äquivalenzklasse enthaltende Information nicht mittels der Qualifizierung von Feldwerten an Raumzeitpunkten darstellen lässt, ist eine der Ursachen dafür, dass die Diffeomorphismus-Invarianz von manchen Physikern, vor allem von den Vertretern der Loop Quantum Gravity, als Anzeichen für die Relationalität der Raumzeit angesehen wird.

"But we have learned another more general lesson from GR: that spacetime location is relational only. This is a distinct idea from the fact that the metric is dynamical. Mathematically, this physical idea is captured by the active diff invariance of the Einstein equations." (Rovelli (1998) 18)

Dieser Auffassung zufolge ist schon die Allgemeine Relativitätstheorie eine letztendlich relationale Theorie.

"[...] apart from the specification of topology, differential structure and dimension, general relativity is a relational physical theory." (Smolin (2005) 12)

Diese Einsicht sollte sich, jedenfalls nach Auffassung der Vertreter des Raumzeitrelationalismus, auch in einer Quantengravitationstheorie niederschlagen. Sie gehört immerhin zu den Grundüberzeugungen, auf denen etwa die Loop Quantum Gravity beruht. 
"Therefore, what we need in quantum gravity is a relational notion of a quantum spacetime." (Rovelli (1998) 19)

Über diesen engeren Kontext hinaus, ist die Relationalität der allgemeinrelativistischen Raumzeit jedoch innerhalb der Physik wie der Wissenschaftstheorie immer noch umstritten. Der Streit zwischen den Substantivalisten und den Relationalisten ist noch lange nicht ausgefochten. ${ }^{331}$

Unumstritten ist jedoch die Dynamizität der allgemein-relativistischen Raumzeit: Wenn eine Theorie der Quantengravitation nicht hinter diese Einsicht der Allgemeinen Relativitätstheorie zurückfallen will, so kann eine solche Theorie nicht auf einer (direkten oder indirekten) Quantisierung der Gravitation auf einer fest vorgegebenen, statischen Hintergrundraumzeit beruhen. Aber nicht nur die erfolglosen Ansätze zur Einbeziehung der Gravitation in den methodologischen Rahmen der Quantenfeldtheorien ("Kovariante Quantisierung") gingen von einer solchen fest vorgegebenen, statischen Hintergrundraumzeit aus, auf der die Gravitation und ihre Dynamik beschrieben werden sollte. Das gleiche Problem stellt sich für den Stringansatz. Dieser arbeitet, wie schon die Quantenfeldtheorien, auf einer modelltheoretischen Grundlage, die vom konzeptionellen Ansatz her eine fixierte Raumzeit, meist eine klassische, statische Minkowski-Raumzeit, voraussetzt. ${ }^{332}$ Die Dynamik des String wird auf einer einmal festgelegten, nicht in die Dynamik einbezogenen Hintergrundraumzeit beschrieben, wie sie schon die Quantenfeldtheorien verwenden. Dies entspricht letztlich dem Versuch, die dynamische Raumzeit - deren Metrik gemäss der Allgemeinen Relativitätstheorie der Gravitation entspricht, die dann im Bild der Quantenfeldtheorien als durch den Austausch von Gravitonen (den Feldquanten des quantisierten Gravitationsfeldes bzw. des quantisierten metrischen Feldes) zustandekommendes Phänomen aufgefasst wird und die schliesslich im Stringansatz als Ergebnis der Wechselwirkung von Strings im Spin-2-Oszillationszustand verstanden wird - auf einer fest vorgegebenen, statischen Hintergrundraumzeit zu quantisieren.

\footnotetext{
331 Siehe etwa Earman (1986) (1989), Maudlin (1993), Bartels (1994), (1996), (1999) sowie Belot (1996).
}

332 Es gibt zwar vielversprechende Versuche, den Stringansatz auf gekrümmte Metriken zu erweitern. Siehe etwa Sanchez (2003). Diese gekrümmten Metriken werden jedoch immer noch als fest vorgegeben behandelt; sie können im Rahmen der durch das modelltheoretische Instrumentarium der Stringtheorien vorgezeichneten Möglichkeiten nicht als dynamisch ins Geschehen einbezogen behandelt werden. 
Ein solches Vorgehen impliziert gleich zwei Probleme: Zum einen wird die Dynamizität der Raumzeit ignoriert, zum anderen die Tatsache, dass sich die Gravitation im Rahmen der Allgemeinen Relativitätstheorie als metrische Eigenschaft der Raumzeit darstellt, also als solche kaum auf einer schon vorgegebenen Hintergrundraumzeit erfasst werden kann.

Für die frühen Ansätze zur Einbeziehung der Gravitation in den methodologischen Rahmen der Quantenfeldtheorien ("Kovariante Quantisierung") endete diese Vorgehensweise in der Nicht-Renormierbarkeit und bedeutete ihr Aus. Für den Stringansatz scheint sich zwar das Problem der NichtRenormierbarkeit vermeiden zu lassen; durch die Einbeziehung der Supersymmetrie scheint die Theorie finit $\mathrm{zu}$ bleiben und nicht einmal einer Renormierung zu bedürfen, auch wenn dies immer noch nicht definitiv bewiesen worden ist. An der Unverträglichkeit der konzeptionellen Voraussetzungen des Stringansatzes mit den Einsichten aus der Allgemeinen Relativitätstheorie ändert dies jedoch nichts: Eine Beschreibung der Gravitation müsste, wenn man die Einsichten der Allgemeinen Relativitätstheorie ernst nimmt, ohne einen vorgegebenen Hintergrundraum auskommen. Eine solche Beschreibung kann jedoch nicht im Kontext eines perturbativen Ansatzes erreicht werden, der (wie die Quantenfeldtheorien) notwendigerweise mit einem fest vorgegebenen Hintergrundraum arbeitet. ${ }^{333}$

Diese konzeptionellen Unzulänglichkeiten stellen nicht zuletzt auch in Frage, dass sich der Stringansatz im Hinblick auf seine theoretischen Implikationen (Dimensionalität, Kompaktifizierung, aber auch Stringdynamik und -Oszillationen) überhaupt realistisch interpretieren lässt. ${ }^{334}$

"It is most likely irrelevant whether these extra dimensions exist in any literal sense. If one is drawn to a picture of our three-dimensional 'reality' embedded in some higher-dimensional realm, then one can believe in the extra dimensions, at least as long as one is working in this background dependent picture. But these extra dimensions can also be seen as purely theoretical devices which are useful for under-

333 Gerade für den Bereich sehr hoher Energien und sehr kleiner Abstände, für den eine Erfassung der Quanteneigenschaften der Geometrie unabdingbar ist, brechen ohnehin die Voraussetzungen für eine perturbative quantenfeldtheoretische Behandlung zusammen.

334 Von diesem Problemen einer realistischen Deutung des vom Stringansatz gezeichneten Bildes des dynamischen Geschehens auf der Planck-Ebene wird später noch ausführlicher die Rede sein. Siehe Kap. 7. 
standing the list of consistent string theories in three dimensions. As long as we stay on the background dependent level, it does not really matter." (Smolin (2000) 160)

Das Problem der fest vorgegebenen Hintergrundraumzeit existiert als konzeptionelles Problem zwar grundsätzlich auch schon für die Quantenfeldtheorien. ${ }^{335}$ Es nimmt aber hier nicht die sich für den Stringansatz abzeichnende Brisanz an, da mit letzterem, im Gegensatz zu den Quantenfeldtheorien, gerade die dynamische Erfassung der Gravitation geleistet werden soll. Dass die Raumzeitkonzeption der Quantenfeldtheorien nicht mit der der Allgemeinen Relativitätstheorie vereinbar ist, ist letztendlich nur eines der Anzeichen für deren wechselseitige Inkompatibilität, die gerade eine wichtige Motivation für die Entwicklung einer Theorie der Quantengravitation liefert. Wenn sich der Stringansatz jedoch mit grundlegenderen Auffassungen hinsichtlich der Raumzeit als in jeder Hinsicht unverträglich erweisen sollte, so liefert dies im Gegensatz zu dem für die Quantenfeldtheorien diesbezüglich vorliegenden Problem keine weiteren Motivationselemente mehr, die über den Kontext des theoretischen Ansatzes hinausdeuten, sondern bedeutet lediglich sein Ende. Gerade eine Theorie der Quantengravitation kann die Problematik der Raumzeit als konzeptionelles Problem nicht ignorieren.

\section{Raumzeit als abgeleitete Grösse ?}

Das Problem der Hintergrundraumzeit und seine Brisanz werden von den Stringtheoretikern ohne Umschweife als solche erkannt. ${ }^{336}$

"Finding the correct mathematical apparatus for formulating string theory without recourse to a pre-existing notion of space and time is one of the most important issues facing string theorists. An understan-

335 Es gibt, wenn man die von den Quantenfeldtheorien beschriebenen Zustände im Energie-Impuls-Tensor der Allgemeinen Relativitätstheorie berücksichtigt, eine Rückwirkung dieser Zustände auf die Raumzeit, die nur in einem iterativen Näherungsprozess, beginnend mit einer Testmetrik, erfasst werden kann. Dies setzt voraus, dass der Iterationsprozess der Berechnung konvergiert. Dafür gibt es aber keine Garantien.

$336 \quad$ Siehe vor allem auch Seiberg (2006). 
ding of how space and time emerge would take us a huge step closer to answering the crucial question of which geometrical form actually does emerge." (Greene (1999) 380)

Die zur Zeit angedachten, aber bisher allesamt nicht konkret ausformulierten Lösungsansätze, die konzeptionelle Unverträglichkeit des Stringansatzes mit den sich aus der Allgemeinen Relativitätstheorie ergebenden Einsichten hinsichtlich der Raumzeit zu überwinden, gehen nahezu einmütig in die Richtung, eine Beschreibung der Stringdynamik anzustreben, in der sich die Raumzeit schliesslich als abgeleitete Grösse ergibt und eben nicht schon vorausgesetzt wird. Die Umstände, unter denen sich die Raumzeit als abgeleitete Grösse ergeben könnte, lassen sich dabei unschwer in drei Varianten unterteilen:

- Eine als dynamische Entität zu verstehende Raumzeit ergibt sich auf der Grundlage einer prägeometrisch zu erfassenden Stringdynamik.

- Raumzeit und Stringdynamik ergeben sich aus einer basaleren prägeometrischen (stringunabhängigen) Dynamik.

- Raumzeit und Stringdynamik werden im Rahmen einer "holographischen" Theorie, die eine Dynamik auf den "Rändern" der Raumzeit beschreibt (bzw. auf einem niederdimensionalen Konfigurationsraum, der nicht mit der Raumzeit der Stringdynamik identisch ist), als quasi "von aussen" erzeugt und determiniert verstanden.

Von diesen drei Varianten bedarf die letzte noch mehr als die beiden vorausgehenden einer detaillierteren Erläuterung, die allerdings, nach einer Erörterung ihrer konzeptionellen Voraussetzungen, erst im Rahmen des nachfolgenden Teilkapitels erfolgen wird. Bisher sind die im folgenden anzusprechenden Ideen als ausschliesslich programmatische Spekulationen ohne formale, modelltheoretische Stützung zu sehen - und dies gemessen am Standard der ohnehin schon hochgradig spekulativen Stringtheorie. 


\section{Raumzeit als Ergebnis einer prägeometrischen Stringdynamik}

Die grundlegende Voraussetzung für die Umsetzung der Idee, dass die Raumzeit durch eine prägeometrische Stringdynamik zustandekommt, ist die Formulierung einer "Stringtheorie", die im Gegensatz zu den bisher vorhandenen perturbativen Stringtheorien ohne einen statischen Hintergrundraum auskommt. Die Raumzeit sollte sich im Rahmen eines solchen Ansatzes als Näherungsergebnis aus der prägeometrischen Stringdynamik für die phänomenologische Ebene darstellen. Für die modelltheoretische Umsetzung dieser Intuition gibt es jedoch bisher bestenfalls punktuelle Ansätze.

Dies hält Edward Witten ${ }^{337}$ aber nicht davon ab, das Problem als eigentlich schon im Wesentlichen gelöst darzustellen. Er behauptet, dass die Einbettung der Stringdynamik in eine zehndimensionale Hintergrundraumzeit schon für die bestehenden perturbativen Stringtheorien lediglich als formales Instrumentarium anzusehen ist, diese Hintergrundraumzeit jedoch letztlich obsolet ist, da sich die Stringdynamik vollständig durch eine zweidimensionale Feldtheorie ersetzen lässt, die auf dem Weltblatt des String definiert ist. Nach Witten ist es nicht erforderlich, eine Hintergrundraumzeit anzunehmen, auf der diese Dynamik stattfindet. Die eigentliche Raumzeit geht nach Wittens Auffassung aus dieser zweidimensionalen Feldtheorie auf dem Weltblatt hervor, ist also schon eine abgeleitete Grösse: ein Näherungsresultat für den klassischen Grenzfall.

"[...] as Witten describes, it is simple to generalize from the assumption of a flat background by inserting your metric of choice into the Lagrangian for the string field. This observation, plus the fact that conformal invariance for the field on the string demands that the Einstein equation be satisfied by the spacetime metric, leads Witten to propose that we should not see spacetime as an absolute background in string theory after all." (Callender / Huggett (2001a) 16)

Das Instrumentarium der perturbativen Stringtheorien spiegelt jedoch Wittens Auffassung in keiner Weise wider. Es ist bisher völlig unklar, wie die Raumzeit aus der zweidimensionalen konformen Feldtheorie auf dem Weltblatt des Strings hervorgehen soll und wie die Interaktionen von

337 Siehe Witten (1993), (1996) sowie Smolin (1998), (2000b), Horowitz (2005). 
Strings beschrieben werden sollen, wenn nicht auf einer schon fest vorgegebenen Hintergrundraumzeit. ${ }^{338}$

Die Vorstellung, dass zumindest die metrischen Eigenschaften der Raumzeit - in einer angemessenen Stringtheorie, wenn es sie schliesslich einmal geben sollte - erst durch die Stringdynamik zustandekommen, ist zwar naheliegend; aber im Stringansatz in seinen bisherigen Formulierungen ist diese Idee kaum umsetzbar. Es gibt bisher bestenfalls wortreiche Intuitionen hinsichtlich des Zustandekommens der Raumzeit auf der Grundlage einer prägeometrischen Stringdynamik: ${ }^{339}$

"[...] we can still ask whether the geometrical model of spacetime that plays such a pivotal role in general relativity and in string theory is solely a convenient shorthand for the spatial and temporal relations between various locations, or whether we should view ourselves as truly being embedded in something when we refer to our immersion within the spacetime fabric. / Although we are heading into speculative territory, string theory does suggest an answer to this question. The graviton, the smallest bundle of gravitational force, is one particular pattern of string vibration. And just as an electromagnetic field such as visible light is composed of an enormous number of photons, a gravitational field is composed of an enormous number of gravitons that is, an enormous number of strings executing the graviton vibra-

338 Auch Michio Kaku weist in seinem Lehrbuch (Kaku (1999) 325f), allerdings in sehr kurzen Andeutungen, auf einen prägeometrischen Ansatz zu einer String Field Theory hin, für den sich gerade die metrischen Eigenschaften des Hintergrundraums erst als Teil der jeweiligen Lösung der Theorie ergeben sollen.

"The novel feature of this approach is that nowhere have we made any mention of the background space-time metric. The background occurs only in the kinetic term, not in the interacting term. In fact, the choice of the background metric emerges when we expand about a classical solution to the equations of motion. This is why this approach is called the 'pregeometrical' theory. In principle, the geometric of space-time should emerge as one among many possible vacua. [...] So far, it can be shown that flat space is a consistent solution [...]. It remains to be seen, however, what other kinds of classical backgrounds can be found as solutions to the equation of motion." (Kaku (1999) 326)

Aber auch dieser prägeometrische Ansatz ist bisher nichts mehr als eine - wenn man seine Hoffnungen auf den Stringansatz setzen möchte - konzeptionell vielleicht sehr angemessene Idee, die allerdings noch keine hinreichend konkrete Ausformulierung erfahren hat.

$339 \quad$ Siehe Greene (1999) 377f. 
tional pattern. Gravitational fields, in turn, are encoded in the warping of the spacetime fabric, and hence we are led to identify the fabric of spacetime itself with a colossal number of strings all undergoing the same, orderly, graviton pattern of vibration. In the language of the field, such an enormous, organized array of similarly vibrating strings is known as a coherent state of string. It's a rather poetic image - the strings of string theory as the threads of the spacetime fabric - but we should note that its rigorous meaning has yet to be worked out completely. I Nevertheless, describing the spacetime fabric in this string-stitched form does lead us to contemplate the following question. [...] we can ask ourselves whether there is a raw precursor to the fabric of spacetime - a configuration of the strings of the cosmic fabric in which they have not yet coalesced into the organized form that we recognize as spacetime. Notice that it is somewhat inaccurate to picture this state as a jumbled mass of individual vibrating strings that have yet to stitch themselves together into an ordered whole because, in our usual way of thinking, this presupposes a notion of both space and time - the space in which a string vibrates and the progression of time that allows us to follow its changes in shape from one moment to the next. But in the raw state, before the strings that make up the cosmic fabric engage in the orderly, coherent vibrational dance we are discussing, there is no realization of space and time. [...] In a sense, it's as if individual strings are 'shards' of space and time, and only when they appropriately undergo sympathetic vibrations do the conventional notions of space and time emerge." (Greene (1999) 377f)

Die Grundintuition Brian Greenes ist also: Wenn sich die Raumzeit bzw. ihre metrischen Eigenschaften im Sinne der Allgemeinen Relativitätstheorie auf Gravitationsfelder zurückführen lassen, und wenn Gravitationsfelder im Sinne der Quantenfeldtheorien durch Gravitonen, die Feldquanten des quantisierten Gravitationsfeldes, realisiert werden, und wenn Gravitonen im Sinne des Stringansatzes Oszillationszustände von Strings sind, so sollte sich die Raumzeit bzw. mindestens ihre metrischen Eigenschaften konsequenterweise auf Strings und ihre Dynamik zurückführen lassen, so dass diese Dynamik ohne eine vorauszusetzende Raumzeit mit festgelegten metrischen Eigenschaften auskommen müsste. Die metrischen Eigenschaften der Raumzeit, wenn nicht diese selbst, sollten erst durch die Stringdynamik konstituiert werden. - Das klingt zwar als konzeptionelle Idee sehr vernünftig, aber es ist die Frage, ob sich diese Intuition formal im 
Stringansatz umsetzen lassen wird, oder vielleicht doch eher in den Kontext der Loop Quantum Gravity oder den einer Synthese zwischen beiden Ansätzen gehört. ${ }^{340}$

\section{Raumzeit und Strings als Ergebnis einer (stringunabhängigen) prägeometrischen Dynamik}

Eine solche Synthese von Ideen aus dem Stringansatz und aus der Loop Quantum Gravity klingt auch in einer Alternative zu den vorausgehend geschilderten Intuitionen an. Diese beruht auf der Vorstellung, dass sowohl die Raumzeit als auch die Dynamik der Strings als abgeleitete Grössen aus einer basaleren prägeometrischen Dynamik resultieren könnten. Abhay Ashtekar zufolge könnte es eine stringunabhängige Prägeometrie im Sinne der Loop Quantum Gravity sein, die Raumzeit und Strings hervorbringt:

"In loop quantum gravity, the micro-state representing Minkowski space-time will have a highly non-trivial Planck-scale structure. The basic entities will be 1-dimensional and polymer-like. Even in absence of a detailed theory, one can tell that the fluctuations of these 1dimensional entities will correspond not only to gravitons but also to other particles, including a spin-1 particle, a scalar and an anti-symmetric tensor. These 'emergent states' are likely to play an important role in Minkowskian physics derived from loop quantum gravity. A detailed study of these excitations may well lead to interesting dynamics that includes not only gravity but also a select family of nongravitational fields. It may also serve as a bridge between loop quantum gravity and string theory. For, string theory has two apriori elements: unexcited strings which carry no quantum numbers and a background space-time. Loop quantum gravity suggests that both could arise from the quantum state of geometry, peaked at Minkowski (or, de Sitter) space. The polymer-like quantum threads which must be woven to create the classical ground state geometries could be interpreted as unexcited strings. Excitations of these strings, in turn, may provide interesting matter couplings for loop quantum gravity." (Ashtekar (2005) 32)

340 Siehe den letzten Abschnitt von Kap. 3. 
Eine solche Quanten-Prägeometrodynamik im Sinne einer erweiterten Loop Quantum Gravity könnte vielleicht gerade die Konkretisierung der oben angesprochenen Intuition von Brian Greene liefern, bleibt aber bisher ebenfalls im Rahmen des ausschliesslich Programmatischen.

\section{Raumzeit und Strings als Ergebnis einer Festlegung des raumzeitlichen Geschehens "von aussen" - im Sinne des holographischen Prinzips}

Die letzte der hier anzuführenden Ideen für eine Generierung von Raumzeit (und Strings) aus einer basaleren prägeometrischen Dynamik ist wesentlich radikaler. Sie geht von einer holographischen Generierung des gesamten raumzeitlichen Geschehens durch eine Dynamik aus, die auf einer im Infiniten anzusiedelnden Grenzfläche definiert ist und in deren Kontext es weder Strings noch Gravitation gibt:

"If space and time are not fundamental, what replaces them? Here the answer is that there is an auxiliary spacetime metric which is fixed by the boundary conditions at infinity. The CFT uses this metric, but the physical spacetime metric is a derived quantity. It is important to emphasize that the spacetime is not emerging from the 'strings'. In this approach, the so-called fundamental strings of string theory are also derived quantities. Both the strings and spacetime are constructed from the CFT." (Horowitz (2005) 15)

Diese Idee und das ihr zugrundeliegende holographische Prinzip - sowie schliesslich deren Umsetzung im Rahmen der AdS/CFT-Korrespondenz des Stringansatzes - werden im nun folgenden zweiten Teilkapitel auszuführen und in ihrer möglichen Relevanz zu erörtern sein.

341 "CFT" steht für konforme Feldtheorie; siehe den vorletzten Abschnitt von Kap. 6.2. 


\subsection{Entropie Schwarzer Löcher, diskrete Raumzeit und holographisches Prinzip}

Angesichts der vorausgehend geschilderten Ideen hinsichtlich des Zustandekommens von Raumzeit im Kontext der Quantengravitation, aber ebenso auch gänzlich unabhängig von diesen, stellt sich die Frage, ob die Raumzeit - als abgeleitete oder auch als basale Entität - tatsächlich ein Kontinuum darstellt, wie es nicht zuletzt unsere am besten etablierte Theorie über die Beschaffenheit und das Verhalten der Raumzeit, die Allgemeine Relativitätstheorie, annimmt.

Die zur Zeit eindeutigsten Indizien für eine in letzter Instanz diskrete Raumzeit gehen - unabhängig von allen spekulativen Szenarien, die sich im Rahmen der labyrinthischen Verzweigungen in der Entwicklung einer Theorie der Quantengravitation ergeben haben oder ergeben könnten - auf die im folgenden zu erörternden Überlegungen zur Entropie Schwarzer Löcher und auf das durch diese Überlegungen motivierte holographische Prinzip zurück. Diese Überlegungen könnten sich nach heutiger Einschätzung für eine Theorie der Quantengravitation ohne weiteres als hochgradig relevant herausstellen und wären damit wohl die ersten konzeptionellen Randbedingungen dieser zu entwickelnden Theorie, die sich nicht unmittelbar aus den Vorgängertheorien ergeben würden. Erste Anzeichen für die Relevanz der Entropie Schwarzer Löcher und des holographischen Prinzips finden sich, wie zu erläutern sein wird, tatsächlich auch schon im Stringansatz. $^{342}$

\section{Die Entropie Schwarzer Löcher}

1972 kam Jacob Bekenstein zu der Auffassung, dass Schwarze Löcher eine Entropie besitzen müssen, wenn nicht der Entropiesatz der Thermodynamik grundlegend falsch sein sollte; hätten sie nämlich keine Entropie, so

342 Auch in der Loop Quantum Gravity finden sie Eingang, was hier jedoch nicht weitergehend zu erörtern sein wird. 
würde die Entropie insgesamt abnehmen, wenn Materie in ein Schwarzes Loch fällt. ${ }^{343}$ Bekensteins Ziel war die Entwicklung eines verallgemeinerten Entropiesatzes der Thermodynamik, der auch für Schwarze Löcher seine Gültigkeit behält. Die Frage, die sich ihm diesbezüglich stellte, war, wie gross die Entropie Schwarzer Löcher wohl sein mag und von welchen Determinanten sie abhängt. Hier kam ihm schliesslich eine parallel verlaufende Entwicklung zugute: James Bardeen, Brandon Carter und Stephen Hawking fanden etwa zur gleichen Zeit, zu der Bekenstein über den verallgemeinerten Entropiesatz nachdachte, heraus, dass Schwarze Löcher im Rahmen der Allgemeinen Relativitätstheorie basalen Gesetzen gehorchen, die denen der gewöhnlichen Thermodynamik formal analog sind, wenn man annimmt, dass die Entropie Schwarzer Löcher proportional zur Fläche ihres Ereignishorizontes ist, und wenn man die Oberflächenschwerkraft als proportional zur Temperatur setzt. ${ }^{344}$ Bekenstein kam zu der Überzeugung, dass die sich in dieser formalen Analogie ergebende Entropie nicht nur das Resultat einer Gedankenspielerei ist, sondern Schwarzen Löchern im Rahmen eines verallgemeinerten Entropiesatzes tatsächlich zugeschrieben werden muss.

Wenn die "Bekenstein-Hawking-Entropie", die Schwarzen Löchern mit Hilfe von Analogien, die sich aus dem Kontext der Allgemeinen Relativitätstheorie motivieren lassen, und unter der Annahme der umfassenden Gültigkeit des Entropiesatzes der Thermodynamik zugeschrieben werden kann, proportional zur Fläche ihres Ereignishorizontes ist, bleibt immer noch die Frage nach dem Proportionalitätsfaktor. Eine Antwort auf diese Frage ergab sich schon 1974, als Hawking die Idee entwickelte und ausformulierte, dass Schwarze Löcher infolge von Quanteneffekten an ihrem Ereignishorizont nicht gänzlich schwarz sind, sondern eine thermische Schwarzkörperstrahlung aussenden: die "Hawking-Strahlung". ${ }^{345}$ Diese Hawking-Strahlung liefert den Proportionalitätsfaktor zwischen der Oberflächengravitation des Schwarzen Lochs und seiner Temperatur und schliesslich ebenso den zwischen seiner Entropie und der Fläche seines Ereignishorizontes:

343 Siehe etwa Bekenstein (1973), (1974), (2000), (2001) (2003), Wald (2001), Bousso (2002).

344 Siehe Bardeen / Carter / Hawking (19734).

345 Siehe Hawking (1974) und (1975). Siehe ebenso Kap. 4.2. 
"Aus der Hawking-Strahlung lässt sich die Proportionalitätskonstante zwischen der Entropie Schwarzer Löcher und der Fläche ihres Ereignishorizontes bestimmen: Die Entropie eines Schwarzen Lochs ist exakt gleich einem Viertel seiner Horizontfläche, gemessen in PlanckFlächen." (Bekenstein (2003) 38)

Wenn die Entropie Schwarzer Löcher proportional zur Fläche des Ereignishorizontes ist und (bis auf die Boltzmann-Konstante der Thermodynamik) einem Viertel der Planck-Quadrate innerhalb dieser Fläche entspricht, so bedeutet dies, dass jeweils vier Planck-Quadrate auf dem Ereignishorizont einem Freiheitsgrad des zugrundeliegenden Systems entsprechen. Damit führt die Entropie Schwarzer Löcher sehr schnell zu Werten, die um viele Grössenordnungen über den Entropiewerten gewöhnlicher (aber auch ungewöhnlicherer) Materieansammlungen liegen:

"Note that black hole entropy is large. A neutron star with one solar mass has entropy of the order of $S \sim 10^{57}$ (in units where $k_{B}=1$ ) in a region within a radius of about $10 \mathrm{Km}$. A solar mass black hole has an entropy of $10^{79}$ in a region within a radius of $3 \mathrm{Km}$. There is a huge difference in entropy for these two objects of about the same size [...]." (Lemos (2005) 8)

Es stellt sich dann sofort die Frage, wie die Bekenstein-Hawking-Entropie Schwarzer Löcher zustandekommt. - Gewöhnlich ist die Entropie eine statistische Grösse, die auf die Mikrozustände des entsprechenden Systems zurückgeht. Auf welche Mikrozustände geht aber die BekensteinHawking-Entropie Schwarzer Löcher zurück?

Im Rahmen der Allgemeinen Relativitätstheorie kommen Schwarzen Löchern nur drei physikalische Eigenschaften zu: Masse, elektrische Ladung und Drehimpuls. Die Bekenstein-Hawking-Entropie kann kaum auf diese Eigenschaften zurückgehen. Wenn sie dem Schwarzen Loch zugeschrieben werden kann, dann ist ein Schwarzes Loch etwas grundlegend anderes als das, was die Allgemeine Relativitätstheorie darunter versteht. Worin könnten aber die von der Allgemeinen Relativitätstheorie offensichtlich nicht erfassten Mikrozustände bestehen, auf die die BekensteinHawking-Entropie Schwarzer Löcher zurückzuführen ist? 
"What is the statistical mechanical origin of the black hole entropy $S_{B H}=a_{h o r} / 4 l_{P l}^{2}$ ? What are the microscopic degrees of freedom that account for this entropy? [...] Where do all these states reside? To answer these questions, in the early nineties John Wheeler suggested the following heuristic picture, which he christened 'It from Bit'. Divide the black hole horizon in to elementary cells, each with one Planck unit, $l_{P l}^{2}$, of area and assign to each cell two microstates, or one 'bit'." (Ashtekar (2002) 11)

Die Unterteilung des Ereignishorizontes eines Schwarzen Lochs in PlanckZellen erklärt noch keineswegs das tatsächliche quantenphysikalische $\mathrm{Zu}$ standekommen der Bekenstein-Hawking-Entropie, sondern lediglich die Grössenordnung auf der man die entsprechenden Mikrozustände erwarten kann. ${ }^{346}$ Es gibt zwar inzwischen ein ganzes Spektrum an Spekulationen, ${ }^{347}$ nicht zuletzt aus dem Kontext der Loop Quantum Gravity, ${ }^{348}$ aber keine eindeutige Lösung für dieses Problem. ${ }^{349}$

346 Dass sich die Ableitung der Bekenstein-Hawking-Entropie als Kombination aus Komponenten, welche die Allgemeine Relativitätstheorie, die Quantenmechanik bzw. Quantenfeldtheorie und die Thermodynamik einbeziehen, darstellt, insbesondere aber auch die Entropieabzählung durch Planck-Flächen, deutet schon auf den Kontext der Quantengravitation hin:

"Also correct, it seems, is to understand that this is a manifestation of quantum gravity, so that one should divide the area by the Planck area, and multiply by the Boltzmann constant to convert from the usual area units into the usual entropy units." (Lemos (2005) 6)

$347 \quad$ Siehe etwa Lemos (2005).

348 Rafael Sorkin bezweifelt jedoch, dass die Loop Quantum Gravity überhaupt in der Lage sein könnte, eine angemessene Lösung dieses Problems zu liefern:

"[...] an approach like canonical quantum gravity, which formulates its dynamics in terms of data on a purely spatial 3-manifold, cannot do justice to black hole thermodynamics, and in particular to the generalized second law." (Sorkin (2005) 9)

349 Es ist schon strittig, ob die Bekenstein-Hawking-Entropie überhaupt dem Schwarzen Loch selbst zuzuschreiben ist oder vielmehr, wie etwa Sorkin (Sorkin (2005)) behauptet, die Freiheitsgrade auf dem Ereignishorizont des Schwarzen Lochs erfasst.

"[...] it is sometimes maintained that the entropy of a black hole refers to degrees of freedom of the interior region [...] If this were so, however, it is difficult to see how one could ever hope to account for the generalized second law." (Sorkin (2005) 4) 
"What is the microscopic, statistical origin of black hole entropy? We have learned that a black hole, viewed from the outside, is unique classically. The Bekenstein-Hawking formula, however, suggests that it is compatible with $e^{S B H}$ independent quantum states. The nature of these quantum states remains largely mysterious." (Bousso (2002) 7)

\section{Die holographische Informationsdichtegrenze}

Was die Bekenstein-Hawking-Entropie interessant macht, auch wenn die Frage nach den tatsächlichen physikalischen Mikrozuständen, auf deren Grundlage sie zustandekommt, bisher noch ungeklärt ist, ist, dass sie immerhin schon zu einer konkreten Antwort auf die Frage führt, wieviel Komplexität, wieviel Differenziertheit, wieviel Information, wieviel Struktur und Strukturiertheit auf der fundamentalsten Ebene der Natur maximal anzutreffen sein wird.

"How much complexity [...] lies at the deepest level of nature? How much information is required to specify any physical configuration completely, as long as it is contained in a prescribed region." (Bousso (2002) 12)

Die formale Antwort der gesamten bisherigen Kontinuumsphysik, einschliesslich der Quantenfeldtheorien und der Einsteinschen Allgemeinen Relativitätstheorie, auf die Frage nach dem in einem Raumvolumen maxi-

Aber auch wenn Sorkins Auffassung zuträfe, bleibt immer noch unklar, welche Mikrozustände zu den Freiheitsgraden auf der Horizontfläche gehören?

"Similarly, it might be that fluctuations in horizon shape could be taken to be the main source of the entropy of a black hole." (Sorkin (2005) 3)

Unabhängig von dieser offenen Frage kommt Sorkin zu dem Schluss, dass die Entropie Schwarzer Löcher mit ihrer Finitheit ein klares Anzeichen für eine diskrete Raumzeitstruktur ist. - Eine interessante Diskussion dieser Problematik findet sich in Jacobson / Marolf / Rovelli (2005). Die Frage, ob die Bekenstein-Hawking-Entropie dem Schwarzen Loch selbst zuzuschreiben ist oder die Freiheitsgrade auf dem Ereignishorizont Lochs erfasst, relativiert sich jedoch im Rahmen des weiter unten zu besprechenden holographischen Prinzips. 
mal möglichen Informationsgehalt ist immer: unendlich. Die Kontinuumsphysik kennt keine inhärente Grenze für Informationsdichten.

"A quantum field theory consists of one or more oscillators at every point in space. Even a single harmonic oscillator has an infinitedimensional Hilbert space. Moreover, there are infinitely many points in any volume of space, no matter how small." (Bousso (2002) 12)

Die Bekenstein-Hawking-Entropie liefert hingegen, wenn man ihre Implikationen weiter durchleuchtet, eine völlig andere, neue Antwort auf diese Frage. Denn die Entropie Schwarzer Löcher ist, wie sich (unter sehr allgemeinen Voraussetzungen) motivieren lässt, die maximale Entropie, die für ein Raumvolumen erreichbar ist. Sie liefert eine Informationsdichtegrenze, den Wert für eine maximale Informationsmenge, die innerhalb eines definierten Raumvolumens erreicht werden kann. Infolge der Abhängigkeit des entsprechenden Wertes vom Ereignishorizont, also von einer das Raumvolumen einschliessenden Fläche, wird diese Informationsdichtegrenze (aus Gründen, die noch zu erörtern sein werden) als "holographische Grenze" bezeichnet. Dass die holographische Grenze gerade die maximale Informationsdichte erfasst, die innerhalb eines Raumvolumens erreicht werden kann, macht Bekenstein anhand eines einfachen Gedankenexperiments plausibel:

"Die holographische Grenze gibt an, wie viel Information in einem gegebenen Raumgebiet enthalten sein kann. Man betrachtet eine Materieansammlung, die in eine Kugel der Oberfläche A passt und zu einem Schwarzen Loch kollabiert. Die Horizont-Oberfläche des Schwarzen Loches muss kleiner als A sein, seine Entropie somit kleiner als A/4. Da die Entropie nicht abnehmen kann, muss auch die ursprüngliche Materieverteilung weniger als A/4 Entropie- oder Informationseinheiten enthalten haben. Das bedeutet, dass der maximale Informationsgehalt eines Raumgebietes durch dessen Oberfläche festgelegt wird - entgegen der nahe liegenden Annahme, die Speicherkapazität eines Gebiets hänge von seinem Volumen ab." (Bekenstein (2003) 38)

Eine alternative Argumentation für die holographische Grenze beruht auf der Unitarität quantenphysikalischer Prozesse: Formt sich aus einer ausreichend grossen Materieansammlung ein Schwarzes Loch, so kann der In- 
formationsgehalt des die Materie enthaltenden Volumens nicht vorher proportional zum Volumen und hinterher proportional zur umgebenden Fläche sein, wenn die Gesamtinformation erhalten bleiben soll. Genau diese Informationserhaltung kommt in der Unitarität quantenphysikalischer Prozesse zum Ausdruck: ${ }^{350}$

"A more compelling consideration is based on unitarity. Quantummechanical evolution preserves information; it takes a pure state to a pure state. But suppose a region was described by a Hilbert space of dimension $e^{V}$, and suppose that region was converted to a black hole. According to the Bekenstein entropy of a black hole, the region is now described by a Hilbert space of dimension $e^{A / 4}$. The number of states would have decreased, and it would be impossible to recover the initial state from the final state. Thus, unitarity would be violated. Hence, the Hilbert space must have had dimension $e^{A / 4}$ to start with." (Bousso (2002) 14)

$\mathrm{Zu}$ den formalen Voraussetzungen für die Ableitung der holographische Grenze zählt neben dem verallgemeinerten Entropiesatz der Thermodynamik die Annahme nur schwacher Gravitationswirkungen. ${ }^{351}$ Inzwischen wurde von Raphael Bousso, um eine universelle Gültigkeit zu erreichen, eine Verallgemeinerung der holographischen Grenze entwickelt, die ohne letztere Annahme auskommt: die "kovariante Entropiegrenze". ${ }^{352}$ Sollte die kovariante Entropiegrenze, zu der sich noch keine Gegenbeispiele haben finden lassen, universelle Gültigkeit beanspruchen können, so gibt es eine finite maximale Entropie, die für ein Raumvolumen erreichbar ist. Diese finite Entropie entspricht einer finiten maximalen Zahl von Freiheitsgraden, die für dieses Raumvolumen zu berücksichtigen sind:

"Since it involves no assumptions about the microscopic properties of matter, it places a fundamental limit on the number of degrees of freedom in nature." (Bousso (2002) 36)

350 Es ist aber immerhin fraglich, ob die Unitarität auf der Ebene der Quantengravitation noch eine Rolle spielt. Siehe etwa Sorkin (2005).

$351 \quad$ Siehe Bousso (2002).

352 Siehe Bousso (2002). 
Auch wenn die Frage, auf welche Mikrozustände und welche Freiheitsgrade die Bekenstein-Hawking-Entropie Schwarzer Löcher zurückgeht, vorerst ungeklärt bleibt, macht die kovariante Entropiegrenze schon deutlich, dass innerhalb eines Raumvolumens immer nur eine finite maximale Information kodiert werden kann. Es gibt in der Natur offensichtlich eine maximale Informationsdichte. ${ }^{353}$ Dies spricht für ein basales, diskretes Substrat, das sich, den numerischen Werten zufolge, auf der Planck-Ebene festmachen lässt. ${ }^{354}$ Die nomologische Erfassung der dort anzutreffenden Strukturen ist aber gerade das Anliegen der Theorieansätze zur Quantengravitation. Die Frage nach den Mikrozuständen, die für die BekensteinHawking-Entropie Schwarzer Löcher und die holographische Grenze (bzw. die kovariante Entropiegrenze) verantwortlich sind, wäre also gerade von einer solchen Theorie der Quantengravitation zu beantworten.

"The covariant entropy bound is a law of physics which must be manifest in an underlying theory. This theory must be a unified quantum theory of matter and space-time. From it, Lorentzian geometries and their matter content must emerge in such a way that the number of independent quantum states describing the light-sheets of any surface B is manifestly bounded by the exponential of the surface area." (Bousso (2002) 37) - "We conclude that the fundamental theory responsible for the [holographic] bound unifies matter, gravity, and quantum mechanics." (Bousso (2002) 37)

Innerhalb einer Theorie der Quantengravitation müsste sich das explizite Zustandekommen der Informationsdichtegrenze klären lassen. Sie müsste sich als Folge der fundamentalen Strukturebene und ihrer Beschaffenheit ergeben. Soweit sind die bestehenden Ansätze zu einer solchen Theorie der Quantengravitation aber noch lange nicht. Immerhin lässt sich jedoch schon die Bekenstein-Hawking-Entropie innerhalb des Stringansatzes formal reproduzieren, allerdings nur für den Spezialfall extremaler (und teilweise höherdimensionaler) Schwarzer Löcher ohne Oberflächentemperatur, die als spezifische String-D-Bran-Konstellationen erfasst werden. Die Modellierung erfolgt auf der allgemein-relativistisch betrachtet vollkom-

353 Dies lässt sich vielleicht auch als Anzeichen für ein computationales Universum lesen. Siehe Lloyd (2005). Lloyds Ansatz lässt sich als Weiterentwicklung von Wheelers "It from bit"-Konzeption ansehen.

354 Dies impliziert nicht zuletzt auch eine diskrete Raumzeitstruktur. Siehe weiter unten. 
men unrealistischen, flachen Raumzeit des Stringansatzes, so dass es eigentlich gar keinen Ereignishorizont gibt und kein Schwarzes Loch im allgemein-relativistischen Sinne. ${ }^{355}$ Dieser relativ zweifelhafte Erfolg lässt sich aber vielleicht immerhin schon als Anzeichen dafür werten, dass der Stringansatz sich auf die fundamentalste nomologische Ebene bezieht. $\mathrm{Ob}$ er dies in konzeptionell angemessener oder in parametrisch geschickter Weise tut, ist eine andere Frage.

\section{Diskrete Raumzeit}

Die Bekenstein-Hawking-Entropie Schwarzer Löcher und die holographische Informationsdichtegrenze (bzw. die kovariante Entropiegrenze) lassen es, indem sie auf eine diskrete Substratstruktur hinweisen, insbesondere auch als höchst fragwürdig erscheinen, die Raumzeit als kontinuierliche Grösse anzusehen, wie sie sich im Rahmen der Allgemeinen Relativitätstheorie darstellt, aber ebenso auch im Rahmen der Quantenfeldtheorien und mithin im Stringansatzes unreflektiert behandelt wird. So wie die Informationsdichtegrenze auf eine tiefste Strukturebene hindeutet, impliziert sie gleichzeitig auch eine diskrete Raumzeitstruktur. Das heisst aber, dass der perturbative Stringansatz, auch wenn sich die Bekenstein-HawkingEntropie auf der Grundlage einiger zaghafter nicht-perturbativer Erweiterungen unter sehr spezifischen Bedingungen reproduzieren lässt, für eine Erfassung der diskreten Substratstruktur, die den Bereich der Quantengravitation mutmasslich auszeichnet, letztlich unangemessen ist. Denn perturbative, feldtheoretische Methoden setzen notwendigerweise ein Raumzeitkontinuum voraus.

"Perturbative treatments pre-suppose that the space-time can be assumed to be a continuum at all scales of interest to physics under consideration." (Ashtekar (2005) 13)

355 Siehe etwa Strominger / Vafa (1996), Das / Mathur (2001), Peet (1998) (2001), Maldacena (1996), Bigatti / Susskind (2001a), David / Mandal / Wadia (2002) und Horowitz (1997). 
Sowohl die Quantenfeldtheorien als auch der Stringansatz implizieren infinite Informationsdichten, die der kovarianten Entropiegrenze eklatant widersprechen. ${ }^{356}$

"Ein Feld wie das elektromagnetische variiert kontinuierlich von Punkt zu Punkt und enthält darum unendlich viele Freiheitsgrade. Auch in Superstring-Theorien ist die Zahl der Freiheitsgrade unendlich. Doch die Holographie beschränkt die Freiheitsgrade innerhalb einer Grenzfläche auf eine endliche Anzahl; folglich kann die Feldtheorie mit ihren Unendlichkeiten nicht das letzte Wort sein." (Bekenstein (2003) 41)

Perturbative, feldtheoretische Methoden sind zur Erfassung der Ebene der Quantengravitation wahrscheinlich letztendlich vollkommen ungeeignet. Sie lassen sich vermutlich bestenfalls als effektive Theorien für einen niedrigeren Energiebereich als den der Quantengravitation ansehen.

356 Für die Unangemessenheit der Kontinuumshypothese in der Quantengravitation gibt es immerhin schon Anzeichen im Kontext der neueren Entwicklungen innerhalb des Stringansatzes, insbesondere und in ziemlich konkreter Form im Matrixansatz zur M-Theorie.

"Moreover, there is a sense in which the spacetime coordinates for D-Branes are elevated from numbers to matrices [...]; only at low energy the matrices are diagonal and an ordinary spacetime picture holds." (Polchinski (1996) 35)

Der Matrixansatz scheint auf eine nicht-kommutative Geometrie hinauszulaufen, wie sie etwa von Alain Connes zur Zeit entwickelt wird. (Siehe etwa Connes (1998).)

"[...] in the Matrix-theory nonperturbative formulation, the space-time coordinates of the string $x^{i}$ are replaced by the matrices $\left(X^{i}\right)_{m}{ }^{n}$. This can perhaps be viewed as a new interpretation of the space-time structure. The continuous space-time manifold emerges only in the long distance region, where these matrices are diagonal and commute; while the space-time appears to have a noncommutative discretized structure in the short distance regime." (Rovelli (1998) 4)

Auch die sich im Stringansatz im Rahmen der T-Dualität abzeichnenden kleinsten raumzeitlichen Distanzen sprechen für eine diskrete Struktur, die hier aus dem im Rahmen der Kontinuumsmathematik formulierten Konstrukt hervorschimmert. (Weitere Argumente für eine diskrete Raumzeitstruktur und eine kleinste Länge im Stringansatz finden sich etwa in Calmet / Graesser / Hsu (2005).) Aber der Stringansatz ist noch weit von einer Einbeziehung aller dieser Einsichten in einen einheitlichen mathematischen Formalismus entfernt. Der bestehende, vorrangig perturbative Formalismus der Stringtheorien geht immer noch von einem Raumzeitkontinuum aus, auf dem sich die Strings bewegen. 
"The holographic principle implies a radical reduction in the number of degrees of freedom we use to describe nature. It exposes quantum field theory, which has degrees of freedom at every point in space, as a highly redundant effective description, in which the true number of degrees is obscured." (Bousso (2002) 37)

Und diese effektiven Kontinuumstheorien arbeiten, gemessen an der für den Bereich der Quantengravitation anzunehmenden diskreten Struktur, mit viel zu vielen Freiheitsgraden.

"The holographic principle [...] is roughly speaking the statement that quantum field theory overestimates the number of possible states in nature and that in a theory of quantum gravity, this number should be much lower." (Fabinger (2001) 13)

Konsequenterweise sind für effektive Theorien, die auf der Kontinuumsannahme beruhen, nicht zuletzt eine Vielzahl von modelltheoretisch erzeugten Artefakten zu erwarten, die kein Gegenstück in der Natur aufweisen. Das heisst aber letztlich, dass man vermutlich weder aus den Quantenfeldtheorien, noch aus dem perturbativen Stringansatz allzuviel, wenn überhaupt irgendetwas, über die Natur von Raum und Zeit lernen kann. Spätestens für den Bereich der Quantengravitation, der mutmasslich eine diskrete Struktur aufweist, führen diese effektiven Kontinuumstheorien wahrscheinlich zu völlig abstrusen Resultaten.

"The first three stages of developments in quantum gravity taught us many valuable lessons. Perhaps the most important among them is the realization that perturbative, field theoretic methods which have been so successful in other branches of physics are simply inadequate in quantum gravity. The assumption that space-time can be replaced by a smooth continuum at arbitrarily small scales leads to inconsistencies. We can neither ignore the microstructure of space-time nor presuppose its nature. We must let quantum gravity itself reveal this structure to us." (Ashtekar (2005) 10) 


\section{Das holographische Prinzip}

Dass die holographische Grenze bzw. die kovariante Entropiegrenze als Informationsdichtegrenzen eine tiefste strukturelle Ebene der Natur und mithin eine diskrete raumzeitliche Struktur nahelegen, ist vor dem Hintergrund der Erfahrungen mit Kontinuumsmodellen, welche die gesamte Physik bisher weitgehend bestimmt haben, schon erstaunlich genug. Um vieles erstaunlicher und überraschender mag jedoch auf den ersten Blick der "holographische" Aspekt dieser Informationsdichtegrenzen wirken. Dieser holographische Aspekt kommt darin zum Ausdruck, dass die maximale einem Volumen zukommende Entropie, die maximale in einem Volumen enthaltene Informationsmenge und die grundsätzlich finite Zahl der Freiheitsgrade, durch die sich die in einem Volumen anzutreffenden physikalischen Zustände (welcher Art diese auch immer sein mögen) kennzeichnen lassen, nicht etwa proportional zu diesem Volumen sind. Vielmehr sind sie proportional zur umschliessenden Fläche bzw. - im Sinne der kovarianten Entropiegrenze - zu einer für die betreffende Raumzeit definierbaren, idealisierten Grenzfläche. Gemessen an dem, was man im Rahmen bisheriger Physik vermuten würde, erscheint diese Proportionalität zwischen der für ein Raumvolumen zulässigen maximalen Information bzw. Strukturiertheit und der für dieses Raumvolumen definierbaren Grenzfläche nicht weniger als völlig kontraintuitiv:

"Naively one would expect the maximal entropy to grow with the volume of spatial regions. Instead, it is set by the area of surfaces." (Bousso (2002) 36)

Solange man annimmt, dass es die Mikrozustände in einem Volumen sind, die dessen Entropie und die in ihm enthaltene Information bestimmen ebenso wie die Zahl der Freiheitsgrade, die zu ihrer Beschreibung nötig sind - bleibt es völlig unverständlich, wieso die maximale Entropie und die maximale Information, die diesem Raumvolumen zugesprochen werden kann, sich proportional zu einer Fläche verhalten sollen, und nicht zu diesem Raumvolumen selbst. Die Proportionalität zwischen dem maximalen Informationsgehalt eines Raumvolumens und dem Flächeninhalt der entsprechenden Grenzfläche bleibt völlig rätselhaft, wenn man annimmt, dass es die Freiheitsgrade im Volumen selbst sind - die Strukturiertheit des physikalischen Geschehens in diesem Raumvolumen -, welche dessen Entro- 
pie und dessen Informationsgehalt festlegen. Anders wäre es, wenn etwa die auf der einschliessenden Oberfläche (bzw. auf einer adäquat zu bestimmenden Grenzfläche) definierbaren Freiheitsgrade die für ein Volumen relevanten Freiheitsgrade schon vollständig festlegten. Die Freiheitsgrade im Volumen wären dann vielleicht nur vermeintliche Freiheitsgrade; sie wären so etwas wie holographische Projektionen von Freiheitsgraden, die auf der Grenzfläche definiert wären. Die eigentlichen Freiheitsgrade des Systems wären, ebenso wie die Dynamik dieses Systems, durch die Freiheitsgrade und die Dynamik auf der entsprechenden Grenzfläche schon festgelegt. Die Zahl der Freiheitsgrade, die einem Raumvolumen zugesprochen werden kann, wäre vollständig erschöpft durch die Freiheitsgrade, die sich für die einschliessende Oberfläche bzw. die Grenzfläche ergeben. Es gäbe keine Information, die das Raumvolumen beträfe, die über die auf der Grenzfläche kodierbare finite Information hinausginge. Die finite maximale Information, die in Bezug auf ein Raumvolumen kodiert werden könnte, wäre deswegen proportional zur Fläche, weil diese Information letztlich gar nicht im Volumen selbst, sondern auf der Fläche kodiert wäre. Das Geschehen im Raumvolumen wäre durch das Geschehen auf der Fläche vollständig festgelegt. Eigentlich gäbe es nur das Geschehen auf dieser Fläche; das Geschehen im Raumvolumen wäre nur ein vermeintliches Geschehen; es wäre eine holographische Projektion des Geschehens auf der Grenzfläche. Dies ist die Idee, die als "Holographisches Prinzip" bezeichnet wird.

"The holographic principle [...] implies that the number of fundamental degrees of freedom is related to the area of surfaces in spacetime." (Bousso (2002) 2)

Treffen die Überlegungen zur Bekenstein-Hawking-Entropie Schwarzer Löcher und zur holographischen Grenze bzw. zur kovarianten Entropiegrenze zu - manifestiert sich diese Grenze also auf der Planck-Ebene, die gerade Gegenstand der in Entwicklung befindlichen Theorien zur Quantengravitation ist -, so sollte sich das holographische Prinzip spätestens in diesem Kontext als relevant erweisen. Genau für diesen Bereich wurde das holographische Prinzip auch Anfang der neunziger Jahre von Gerard 't Hooft und Leonard Susskind formuliert: ${ }^{357}$ Wenn für die fundamentalste Strukturebene gilt, dass die für ein Raumsegment relevanten Freiheitsgrade sich in den Freiheitsgraden erschöpfen, die auf der Grenz-

357 Siehe 't Hooft (1993), Susskind (1995), Bousso (2002), Bekenstein (2003). 
fläche dieses Raumsegments definiert werden können, so sollte es im Rahmen einer adäquaten Theorie der Quantengravitation möglich sein, das raumzeitliche Geschehen vollständig im Rahmen einer Beschreibung zu erfassen, die sich auf das komplementäre Geschehen auf der entsprechenden (idealisierten) Grenzfläche dieser Raumzeit bezieht. Die Freiheitsgrade auf der Grenzfläche würden die Freiheitsgrade in einem Raumvolumen vollständig festlegen. ${ }^{358}$ Eine vollständige Grenzflächen-Theorie würde notwendigerweise auch die Beschreibung aller Prozesse im eingeschlossenen Raumsegment umfassen. Eine vollständige fundamentale Theorie müsste also nur die Freiheitsgrade auf der Grenzfläche berücksichtigen, um alles zu beschreiben, was es zu beschreiben gibt. ${ }^{359}{ }^{360}$ Dies könnte sich vor allem dann als interessant herausstellen, wenn die Erfassung der Flächendynamik viel einfacher ausfällt, als die der Volumendynamik.

\section{AdS/CFT-Korrespondenz}

Interessanterweise findet sich im Stringansatz inzwischen eine konkrete, wenn auch nur für einen Spezialfall motivierbare Umsetzung des holographischen Prinzips. Es ist die sogenannte AdS/CFT-Korrespondenz. ${ }^{361}$ Sie hat den Status einer gut untermauerten Vermutung.

358 Wenn die hinter dem holographischen Prinzip stehenden Überlegungen richtig sind, so entspricht jedes Planck-Quadrat auf der Grenzfläche genau einem Freiheitsgrad.

359 Hierin kommen Anzeichen für ein computationales Universum zum Ausdruck, die noch entscheidend über das entsprechende Argument auf der Grundlage der Diskretheit der Raumzeitstruktur hinausgehen.

Zudem stellt das holographische Prinzip das Konzept der raumzeitlichen Lokalität grundlegend in Frage.

"[...] the holographic principle calls into question [...] the very notion of locality." (Bousso (2002) 2)

360 Rafael Sorkin (Sorkin (2005)) kritisiert das holographische Prinzip und konstatiert, dass die Freiheitsgrade auf der Oberfläche nicht den Zustand im eingeschlossenen Volumen festlegen, aber immerhin ein Indiz für eine diskrete Raumzeitstruktur sind. Siehe auch die Diskussion in Jacobson / Marolf / Rovelli (2005).

361 Die AdS/CFT-Korrespondenz wird, nach ihrem Entdecker Juan Maldacena, auch als "Maldacena Conjecture" bezeichnet. Siehe etwa Maldacena (2003), (2004), Aharony et al. (1999), Klebanov (2001). 
"One cannot prove the AdS/CFT correspondence since we do not have an independent nonperturbative definition of string theory to compare it to." (Horowitz (2005) 11)

Die AdS/CFT-Korrespondenz ist eine Dualitätsbeziehung zwischen einer herkömmlichen Stringtheorie, die auf dem Produkt aus einer fünfdimensionalen Anti-de-Sitter-Raumzeit (AdS) und einem kompakten fünfdimensionalen Raum definiert ist, und einer auf der (idealisierten) Grenzfläche dieser AdS-Raumzeit (plus kompakter fünfdimensionaler Raum) definierten, konform-invarianten Eichtheorie (CFT), die gänzlich ohne Strings auskommt und, abgesehen von ihrer konformen Invarianz, als gewöhnliche Quantenfeldtheorie daherkommt.

"The basic idea of AdS/CFT duality is to identify a conformally invariant field theory (CFT) on the n-dimensional boundary with a suitable quantum gravity theory in the $(n+1)$-dimensional AdS bulk." (Schwarz (1998) 8f)

Konform-invariante Quantenfeldtheorien zeichnen sich nicht zuletzt dadurch aus, dass ihre Kopplungskonstante energieunabhängig ist. Die Quantenfeldtheorien des Standardmodells etwa sind nicht konform-invariant, da sie über energieabhängige Kopplungskonstanten verfügen. Die Stringtheorien hingegen verfügen notwendigerweise über eine konforme Invarianz auf dem Weltblatt der Stringdynamik. Aber im Rahmen der AdS/CFT-Korrespondenz handelt es sich bei der Flächentheorie nun nicht um eine Stringtheorie, der diese Eigenschaft zugesprochen wird, sondern um ein gewöhnliche Feldtheorie.

"AdS/CFT Correspondence: String theory on spacetimes which asymptotically approach the product of anti de Sitter (AdS) and a compact space, is completely described by a conformal field theory 'living on the boundary at infinity'. [...] At first sight this conjecture seems unbelievable. How could an ordinary field theory describe all of string theory?" (Horowitz (2005) 10)

Die auf der Grenzfläche der AdS-Raumzeit definierte konform-invariante Feldtheorie enthält alle Informationen, die sich für die AdS-Raumzeit auf der Grundlage der entsprechenden Stringtheorie ergeben. 
"[...] $N=4 U(N)$ Yang-Mills theory could be the same as ten dimensional superstring theory on $A d S_{5} \times S^{5}$." (Aharony et al. (1999) 6)

Bisher liess sich diese Form von holographischer Korrespondenz jedoch nicht ohne guten Grund nur für den Spezialfall der AdS-Raumzeit motivieren. Die AdS-Raumzeit ist in spezifischer Hinsicht das Gegenstück zur deSitter-Raumzeit, die 1917 von Willem de Sitter als Lösung der Einsteinschen Feldgleichungen gefunden wurde. Die de-Sitter-Raumzeit ist eine maximal-symmetrische Lösung der Einsteinschen Feldgleichungen mit positiver kosmologischer Konstante und leerem Raum; die positive kosmologische Konstante führt hierbei zu einer beschleunigten Ausdehnung. Die Anti-de-Sitter-Raumzeit (AdS) hingegen ist eine maximal-symmetrische Lösung der Einsteinschen Feldgleichungen mit negativer kosmologischer Konstante und leerem Raum. Die negative kosmologische Konstante der AdS-Raumzeit hat eine beschleunigte Kontraktion zur Folge. Gerade dies macht es möglich, räumliche Grenzflächen im Unendlichen zu definieren, die entscheidend sind für die Umsetzung des holographischen Prinzips in der AdS/CFT-Korrespondenz.

Die AdS/CFT-Korrespondenz ist nicht nur deshalb interessant, weil mit ihr im Kontext der Theorieansätze zur Quantengravitation eine erste Umsetzung des holographischen Prinzips gelingt, sondern nicht zuletzt auch, weil sie die Verbindung zwischen einer Gravitationstheorie innerhalb einer ndimensionalen Raumzeit und einer relativ simplen Feldtheorie herstellt, die auf der (n-1)-dimensionalen Grenzfläche dieser Raumzeit definiert ist und die Gravitation überhaupt nicht mehr enthält. ${ }^{362}$

"The theory in AdS includes gravity, since any string theory includes gravity. So in the end we claim that there is an equivalence between a gravitational theory and a field theory. However, the mapping between the gravitational and field theory degrees of freedom is quite

362 Wie sieht nun aber im Fall der AdS/CFT-Korrespondenz die holographische Festlegung im Detail aus? Wie werden die Zustände der vollen Raumzeit auf dem Flächen-Hologramm repräsentiert? Welche Zustände und Dynamiken auf dem Hologramm entsprechen welchen Zuständen und Dynamiken innerhalb der Raumzeit? Ein Beispiel mag der Veranschaulichung dienen:

"A string stretched across the bulk is represented by a point charge in the dual CFT." (Bousso (2002) 40)

Ein weiteres Beispiel findet sich etwa in Trivedi (2001). Siehe auch Maldacena (2004). 
non-trivial since the field theory lives in a lower dimension. In some sense the field theory (or at least the set of local observables in the field theory) lives on the boundary of spacetime. One could argue that in general any quantum gravity theory in AdS defines a conformal field theory (CFT) 'on the boundary'." (Aharony et al. (1999) 8)

Eine holographische Festlegung des Geschehens innerhalb der Raumzeit, wie sie in der AdS/CFT-Korrespondenz zum Ausdruck kommt, hat einschneidende Konsequenzen im Hinblick auf unser Verständnis von Raum, Zeit und Naturgeschehen. Insbesondere macht sie die Annahme des Lokalitätsprinzips innerhalb der Physik zumindest fragwürdig:

"Physics appears to be local to a good approximation. The number of degrees of freedom in any local theory is extensive in the volume. Yet, the holographic principle dictates that the information content is in correspondence with the area of surfaces. How can this tension be resolved? [...] One type of approach aims to retain locality. [...] leaving only as many physical degrees of freedom as dictated by the covariant entropy bound. [...] A second type of approach regards locality as an emergent phenomenon without fundamental significance. [...] One must also explain how to translate underlying data, in a suitable regime, into a classical spacetime inhabited by local quantum fields. [...] The AdS/CFT correspondence lends credence to the second type of approach." (Bousso (2002) 37)

Dies gilt letztlich für jegliche Form einer holographischen Festlegung. Wenn sich die Freiheitsgrade, die scheinbar das lokale Geschehen innerhalb der Raumzeit betreffen, im Rahmen ihrer holographischen Festlegung auf einer Grenzfläche erheblich reduzieren lassen, so deutet dies darauf hin, dass die vermeintlichen Freiheitsgrade des lokalen raumzeitlichen Geschehens vielleicht gar keine echten Freiheitsgrade sind.

Was jedoch hinsichtlich der Umsetzung des holographischen Prinzips im Rahmen der AdS/CFT-Korrespondenz immer noch als problematisch angesehen werden kann, ist die Tatsache, dass die Grenzflächentheorie als konform-invariante Feldtheorie eine Kontinuumstheorie ist, die den vorausgehend erörterten Argumenten für eine diskrete Struktur auf der PlanckEbene in keiner Weise Genüge tut und immer noch mit infiniten Informationsdichten und einer grundsätzlich infiniten Zahl von Freiheitsgraden ar- 
beitet. - Wie könnte jedoch eine Umsetzung des holographischen Prinzips im Bereich der Quantengravitation unter Berücksichtigung der Argumente für eine diskrete Substrat- wie Raumzeitstruktur, finite Informationsdichten und eine finite Zahl von relevanten Freiheitsgraden aussehen?

\section{Das gesuchte fundamentale Prinzip der Quantengravitation?}

Es erscheint vielleicht nicht völlig abwegig zu vermuten, dass gerade das holographische Prinzip gemeinsam mit der Einsicht in die Diskretheit der Raumzeit und der fundamentalen Substratstruktur einen wesentlichen Beitrag zur Formulierung basaler physikalischer Prinzipien für eine noch zu entwickelnde Quantengravitationstheorie liefern könnte.

"[...] the holographic principle [...] should be an important part of the framework of a Planck-scale, background independent quantum theory." (Markopoulou / Smolin (1999) 2)

In ihrer verallgemeinerten Form als kovariante Entropiegrenze setzt die holographische Informationsdichtegrenze, Boussos Auffassung zufolge, in ihrer Ableitung nur wenig an schon bekanntem theoretischem Instrumentarium voraus, was auf eine sehr allgemeine Gültigkeit hinweisen könnte:

"The [holographic] bound is not explained by other laws of physics that are presently known. [...] We conclude that the bound is an imprint of a more fundamental theory." (Bousso (2002) 36)

Mit der AdS/CFT-Korrespondenz im Stringansatz deutet sich die Relevanz des holographischen Prinzips für eine schliesslich anzustrebende nichtperturbative und hoffentlich auch hintergrundunabhängige Verallgemeinerung der bisherigen perturbativen Stringtheorien vielleicht schon an.

"The holographic principle may not only aid the search for other nonperturbative definitions of string theory. It could also contribute to a background-independent formulation that would illuminate the conceptual foundations of string theory." (Bousso (2002) 39) 
Allerdings bleibt, wie erwähnt, bei der AdS/CFT-Korrespondenz die Diskretheitsanforderung immer noch unberücksichtigt.

Unabhängig von den Stringtheorien, haben nun vor einiger Zeit Fotini Markopoulou und Lee Smolin einen Ansatz zur Implementierung des holographischen Prinzips innerhalb einer hintergrundunabhängigen Quantengravitationstheorie entwickelt, bei dem sich die Diskretheitsanforderung ohne weiteres einlösen lassen sollte. ${ }^{363}$ Die Grundidee besteht hierbei darin, die Substratdynamik als eine Dynamik von diskreten Quanteninformationen aufzufassen. Ausgangspunkt ist in diesem Ansatz die Definition holographischer Schirme und ihrer quantenmechanischen Eigenschaften. Die Fläche der Schirme definiert sich dabei erst auf der Grundlage ihrer quantisierten Informationsdurchflusskapazität und nicht etwa umgekehrt. Dies entspricht in gewisser Weise einer Umkehrung des ursprünglichen holographischen Gedankens:

"This leads us to suggest that the Bekenstein bound may be inverted and area be defined to be a measure of the capacity of a screen for the transmission of quantum information." (Markopoulou / Smolin (1999)

3)

Nicht die Fläche definiert den maximal möglichen Informationsdurchfluss; sie ist vielmehr selbst das Ergebnis des jeweiligen quantisierten Informationsdurchflusses. Fläche steht für die Durchflusskapazität von Quanteninformation. Die raumzeitliche Geometrie und die Kausalstruktur werden schliesslich als gegenüber den holographischen Schirmen und ihren jeweiligen quantisierten Informationsflüssen sekundär verstanden; sie erweisen sich als das abgeleitete Resultat des diskreten, quantenmechanischen Informationsdurchflusses durch ein relationales Netzwerk holographischer Schirme. Die Geometrie der Raumzeit wird durch diskrete Quanteninformation und ihren Fluss realisiert. - Eine unmittelbarere Umsetzung von Wheelers Konzept des "It from bit" ist kaum vorstellbar. ${ }^{364}$ Schon in Wheelers Agenda von 1989 für eine zukünftige Theorie, mittels derer die Unvereinbarkeit von Quantenmechanik und Einsteinscher Gravitationstheorie schliesslich überwunden werden soll, findet sich die Empfehlung:

Siehe Markopoulou / Smolin (1999).

364 Vgl. Wheeler (1989). 
"Translate the quantum versions of string theory and of Einstein's geometrodynamics from the language of continuum to the language of bits." (Wheeler (1989) 362) 
